\title{
Floristic composition and community structure along the elevational gradient of Balinsasayao Twin Lakes Natural Park in Negros Oriental, Philippines
}

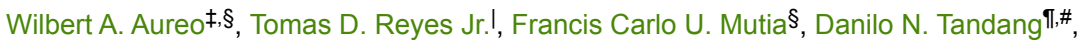 \\ Reizl P. Jose $\$, \S$ \\ ‡ Department of Forestry and Environmental Sciences, College of Agriculture and Natural Resources, \\ Bohol Island State University, Bohol, Philippines \\ $\S$ Program on Biodiversity Assessment and Conservation, Research and Development Office, \\ Bohol Island State University, Bohol, Philippines \\ | Institute of Renewable Natural Resources, College of Forestry and Natural Resources, \\ University of the Philippines Los Baños, Laguna, Philippines \\ If Philippine National Herbarium, Botany and National Herbarium Division, National Museum of Natural History, \\ T.M. Kalaw St., Manila, Philippines \\ \# Biodiversity Program, Taiwan International Graduate Program, Academia Sinica and \\ National Taiwan Normal University, Taipei, Taiwan
}

Corresponding author: Wilbert A. Aureo (wilbert.aureo@bisu.edu.ph)

Academic editor: Stoyan Nedkov

Received: 15 Jul 2020 | Accepted: 11 Dec 2020 | Published: 11 May 2021

Citation: Aureo WA, Reyes Jr. TD, Mutia FCU, Tandang DN, Jose RP (2021) Floristic composition and community structure along the elevational gradient of Balinsasayao Twin Lakes Natural Park in Negros Oriental, Philippines. One Ecosystem 6: e56536. https://doi.org/10.3897/oneeco.5.e56536

\begin{abstract}
Balinsasayao Twin Lakes Natural Park (BTLNP) is one of the protected areas on the Island of Negros Oriental which is enormously rich in biodiversity due to different Lowland types formed along its elevation gradient. This study was conducted to better understand the composition and diversity of plant species in the natural park to improve conservation and management efforts of these remaining forests which are currently under threat from ecotourism and other anthropomorphic influences. Within the 18 randomly distributed nested plots, a total of 351 species of plants were recorded. Of these, 183 species were trees, 54 herbs, 51 shrubs, 41 pteridophytes and 22 vines. The result of hierarchical cluster analysis
\end{abstract}


showed differences in plant composition along the elevation gradient. There were $30(9 \%)$ threatened species (vulnerable, endangered and critically endangered) and most of which were found in the submontane Lowland. Furthermore, the species diversity increases from lowland to sub-montane and eventually decreases towards montane Lowland. These results not only indicate the importance of BTLNP, but also highlights the submontane as a special area of concern due to the higher concentration of threatened and endemic species.

\section{Keywords}

plant conservation, species diversity, Central Visayas, community structure, threatened species

\section{Introduction}

The Philippines is one of the megabiodiverse countries and is considered a priority conservation area (Turner et al. 2003). A recent flora inventory conducted across the Philippines by (Barcelona et al. 2013) reported a total of 10,107 species, which is approximately five percent of the world's known plant species. Primarily due to the economic importance of forests in Southeast Asia, many studies on the flora vegetation have been conducted throughout the Philippines (Whitmore et al. 1984); (Kartawinata 1989); (Soepadmo 1995). However, only a small number of studies have been conducted in the Philippine submontane and montane Lowland regions (Ashton 1993). These regions are one of the the last remaining Lowland fragments in the Philippines and, thus, have become the focus of conservation efforts (Heaney 1993; Penafiel 1995; Hamann et al. 1999). Negros-Panay Region, where this study was conducted, is considered one of the regions most threatened and in need of conservation efforts due to the presences of endemic, critically endangered, and functionally-extinct species (Heaney et al. 1998). Some of these are Prionailurus bengalensis (Heaney et al. 1998), Shorea negrosensis (Fernando et al. 2009), Sus philippinensis and Carlito syrichta (Mallari et al. 2001) to name but a few. One of the primary threats to this area is deforestation which has been shown to be a driver of species extinction in tropical Southeast Asia (Hughes 2017). Prime areas for deforestation within Asian tropics are the lowland forests (Turner and Corlett 1996). However, protected areas are costly and often underfunded which leads to many biologically-important areas being underprotected (Corlett and Primack 2008).

Species diversity can be influenced by many types of environmental changes (Sagar et al. 2008). Different elevations and slopes have shown to influence the species richness and dispersal of tree species (Eilu and Obua 2005). According to Sharma et al. (2009), elevation may cause a difference in the insolation period, thereby forming a range of microclimates in multifaceted landscapes. However, this pattern of biodiversity along the elevational gradient remains relatively poorly understood, partly hindered by the perceived heterogeneous conditions. Understanding biogeographical patterns and variation in species richness and endemic trends is critical to conservation strategies in elevationally- 
diverse areas. Additionally, biodiversity assessments are recognised globally as a fundamental activity to sustainable biodiversity conservation (Humphries et al. 1995, Margules and Pressey 2000, Williams et al. 1995). These combined concepts lead to the present study, an investigation to extend the botanical knowledge of flora composition along elevational range Lowland communities in the context of Southeast Asia. Thus, this study was carried out to answer the following questions: (i) does plant composition changes along elevation gradient and (ii) does species diversity increase with increasing elevation?

\section{Materials and Methods}

\section{Study site}

The Balinsasayao Twin Lakes Natural Park (BTLNP) is located in Negros Oriental and is surrounded by Lakes Balinsasayao and Danao (Fig. 1). It is situated $14.5 \mathrm{~km}$ from Dumaguete City with a total land area of $8,016.65$ hectares $\left(80.16 \mathrm{~km}^{2}\right)$ with elevation ranging from 750 to $1,700 \mathrm{~m}$ above sea level. The topography of BTLNP is generally steep, with fresh and abandoned fields occupying the flatter areas, both within and around the protected area. The lower areas, mainly around the Twin Lakes, still have extensive stands of dipterocarp lowland rainforest, as well as patches of Agathis philippinensis, the largest tree in the Philippines (which can grow up to $60 \mathrm{~m}$ ) (Brooks et al. 1992; Heideman and Erickson 1987; Hicks 2001).

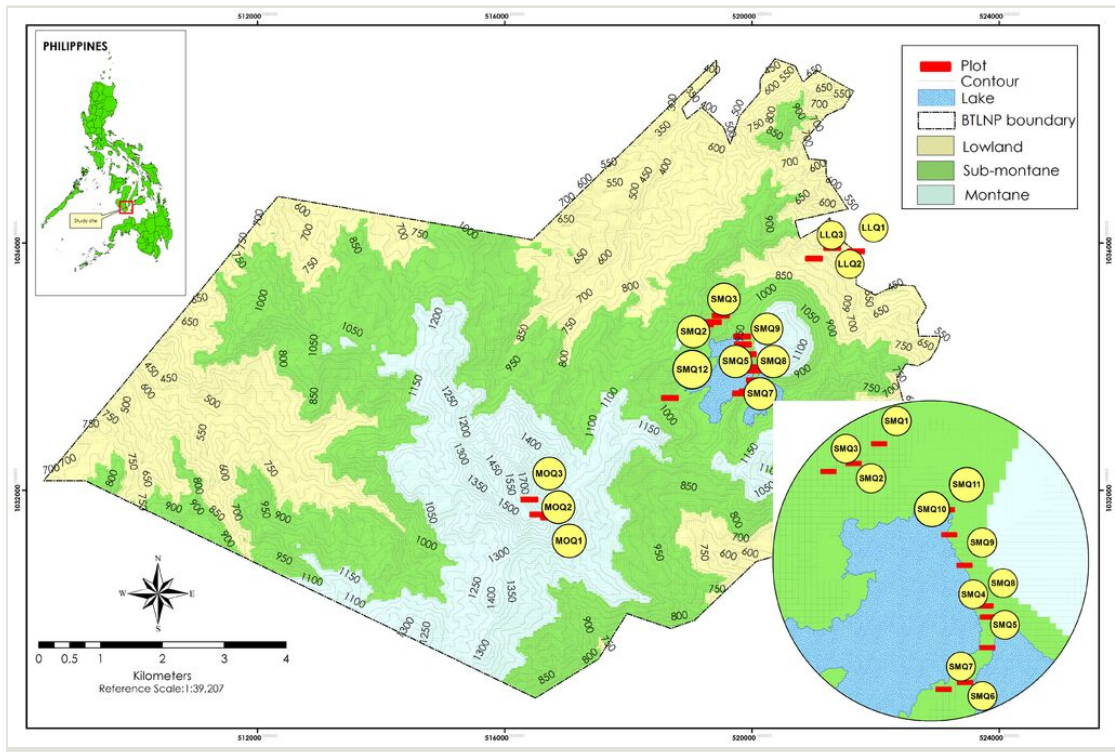

Figure 1.

Location of the established plots (red rectangles) along the elevational gradient of Balinsasayao Twin Lakes Natural Park. 


\section{Field data collection}

The study was conducted along the elevational gradient of Balinsasayao Twin Lakes Natural Park from April to May 2019. Three study forests were pre-determined, based on the general description by Brown and Alcala (1961). The elevation gradients were as follows; lowland Lowland (300-800 m a.s.I.), sub-montane (900-1,450 m a.s.I.) and, lastly, montane that extends to 1,750 m.a.s.l. at the highest peak known as Mt. Guinsayawan (Aureo et al. 2019). Randomly nested sampling plots, designed by Lillo et al. (2019), were used in the flora inventory and data collection procedure. This is to support the initial efforts of the previous researchers to have unified data within the entire region for future unified conservation plans. Eighteen (18) sampling plots (Table 1), each with a dimension of $10 \mathrm{~m}$ x $100 \mathrm{~m}$, were established in the closed and less disturbed forested areas along altitudinal gradients of BTLNP. Each sampling plot was further divided into five (5) equal segments $(10 \mathrm{~m} \times 20 \mathrm{~m})$ to facilitate recording of plants having diameter at breast height (DBH) of 10 $\mathrm{cm}$ and above. A nested subplot of $5 \mathrm{~m} \times 5 \mathrm{~m}$ was laid at the centre of each segment for plants in the intermediate layer which has a diameter at breast hieght (DBH) less than 10 $\mathrm{cm}$. Furthermore, four (4) smallest nested plots $(1 \mathrm{~m} \times 1 \mathrm{~m})$ were also laid on the inner edges of the $5 \mathrm{~m} \times 5 \mathrm{~m}$ plot for species in the understorey layer and ground cover.

Table 1.

The sampling plots in Balinsasayao Twin Lakes Natural Park (BTLNP) with the plot codes (Plots) used in the cluster analysis. Geographic coordinates (latitude, longitude) in each plot are in decimal format and the elevation is in metres above sea level ( $m$ a.s.I.).

\begin{tabular}{|c|c|c|c|c|}
\hline Plot & Forest type & Latitude & Longitude & Elevation ( $m$ a.s.I.) \\
\hline LLQ1 & Lowland & 9.37153 & 123.19747 & 701 \\
\hline LLQ2 & Lowland & 9.37202 & 123.19395 & 680 \\
\hline LLQ3 & Lowland & 9.37048 & 123.19127 & 656 \\
\hline SMQ1 & Sub-montane upper part of the lake & 9.36213 & 123.17753 & 993 \\
\hline SMQ2 & Sub-montane upper part of the lake & 9.36122 & 123.17635 & 1034 \\
\hline SMQ3 & Sub-montane upper part of the lake & 9.36085 & 123.17518 & 1070 \\
\hline SMQ4 & Sub-montane along the lake & 9.35410 & 123.18258 & 886 \\
\hline SMQ5 & Sub-montane along the lake & 9.35268 & 123.18255 & 906 \\
\hline SMQ6 & Sub-montane along the lake & 9.35107 & 123.18152 & 923 \\
\hline SMQ7 & Sub-montane along the lake & 9.35075 & 123.18052 & 895 \\
\hline SMQ8 & Sub-montane along the lake & 9.35462 & 123.18247 & 877 \\
\hline SMQ9 & Sub-montane along the lake & 9.35650 & 123.18150 & 873 \\
\hline SMQ10 & Sub-montane along the lake & 9.35792 & 123.18078 & 867 \\
\hline SMQ11 & Sub-montane along the lake & 9.35908 & 123.18067 & 905 \\
\hline
\end{tabular}




\begin{tabular}{|l|l|l|l|l|}
\hline Plot & Forest type & Latitude & Longitude & Elevation (m a.s.I.) \\
\hline SMQ12 & Sub-montane upper part of the lake & 9.35012 & 123.17003 & 935 \\
\hline MOQ1 & Montane & 9.33265 & 123.15225 & 1670 \\
\hline MOQ2 & Montane & 9.333042 & 123.15063 & 1699 \\
\hline MOQ3 & Montane & 9.335249 & 123.14931 & 1710 \\
\hline
\end{tabular}

Data recorded in the field were:

1. plant names from family down to species level;

2. bio-measurements on diameter at breast height $(\mathrm{cm})$ and total height $(\mathrm{m})$;

3. plant habit of observed plants; and

4. GPS coordinates of all corners of each segment and nested plots.

Relative locations of trees were sketched for tracing and monitoring purposes. For small sized plants (understorey and ground vegetation), these data were obtained:

1. number of individuals and

2. crown cover in percent were estimated.

Identification and nomenclature were aided using the following strategies:

1. expert determination;

2. use of flora databases (Co's Digital Flora of the Philippines 2020; International Plant Name Index (IPNI) 2016),

3. lexicons (Salvosa 1963), Rojo et al. 1999;

4. published books (Flora Malesiana 2019, Merrill 1922), field guides and other literature (e.g. De Guzman et al. 1986; Rojo et al. 1997; Fernando et al. 2004; Lapitan et al. 2010; McPherson and Amoroso 2011; Amoroso 2013; Tandang et al. 2014; and Malabrigo et al. 2016); and finally

5. use of type images.

Herbarium specimens were not collected during the first year of the study because of the limited time and collection restrictions.

\section{Analyses}

The status of plant diversity was assessed using parameters of species abundance, such as: frequency, density and dominance and summed as the importance value. The Importance Value (IV) is the summation of the relative frequency, relative density and relative dominance combined as one.

The formulae to derive the IV are based on Fernando (2008) and are provided below:

Density $=$ total number of individuals of a species / area sampled

Relative Density $=$ density of species $/$ total densities of all species $\times 100$ 
Dominance $=$ basal area $(\mathrm{DBH}$ area $)$ of species $/$ total area sampled

Relative Dominance $=$ dominance of species $/$ total dominance of all species $\times 100$

Occurrence $=$ number of plots a species is observed $/$ total number of plots established

Frequency $=$ number of occurrences $/$ total number of occurrences

Relative Frequency $=$ frequency of species $/$ total of frequencies $\times 100$

Importance value (IV) = Relative Density + Relative Dominance + Relative Frequency

On the other hand, the index of diversity was determined using the equations of Magurran (1998).

Shannon Diversity Index $\left(\mathrm{H}^{\prime}\right)=-\sum \mathrm{p}_{\mathrm{i}}\left(\mathrm{LNp}_{\mathrm{i}}\right)$

where $p_{i}$ is the proportion $(n / N)$ of individuals of one particular species found $(n)$, divided by the total number of individuals found $(\mathrm{N})$

Pielou's Evenness Index $\left(E^{\prime}\right)=H^{\prime} / \ln (s)$

where $\mathrm{s}=$ number of species

Simpson Diversity Index $(D)=1-\left(\sum n(n-1) / N(N-1)\right.$

where $\mathrm{n}=$ the total number of organisms of a particular species; $\mathrm{N}=$ the total number of organisms of all species.

Values were interpreted, using the descriptions (Table 2) proposed by Fernando (2008).

Table 2.

Description of species diversity indices proposed by Fernando (2008).

\begin{tabular}{|l|l|l|}
\hline Relative Value Rating & Species Diversity $\left.\mathbf{H}^{\prime}\right)$ & Evenness (E') \\
\hline Very High & $3.50-$ above & $0.75-1.00$ \\
\hline High & $3.00-3.49$ & $0.50-0.74$ \\
\hline Moderate & $2.50-2.99$ & $0.25-0.49$ \\
\hline Low & $2.00-2.49$ & $0.15-0.24$ \\
\hline Very Low & $0.00-1.99$ & $0.05-0.14$ \\
\hline
\end{tabular}

Hierarchical cluster analysis (HCA) of plots was done using Jaccard's similarity index from Paleontological Statistics (PAST version 2.17c) (Hammer and Harper 2006). The dendogram was generated through the unweighted pair-group method (UPGMA) and bootstrapping $(n=1000)$. We employed this method of analysis because it is sensitive to small sample sizes and missing observations (Glen 2016). 


\section{Threatened species}

The conservation status of species was based on local, "The National List of Threatened Philippine Plants and their Categories" (DENR Administrative Order No. 11-17 2017) and international, the IUCN Red List (International Union for Conservation of Nature's Red List of Threatened Species 2019) catergorisations. Endemicity was determined through a Philippine archive of plant species (Co's Digital Flora of the Philippines 2020) which is available online.

\section{Results}

\section{Floristic composition and community structure}

A total of 351 plant species which represents 230 genera belonging to 103 families were recorded. These species were further classified as 183 species of trees, 54 herbs, 51 shrubs, 41 ferns and 22 vines. Angiosperms dominated the area, comprising 308 different plant species, while only two species were recorded for gymnosperms (Agathis philippinensis and Dacrydium beccarii). At the family level, the top 10 most abundant taxa included Rubiaceae (20 species; 6\%), Lauraceae (19 species; 5\%), Moraceae (18 species, 5\%), Fabaceae (14; 4\%), Myrtaceae (14 species; 4\%), Urticaeae (11 species; 3\%), Araceae (10 species; 3\%), Euphorbiaceae (10 species; 3\%), Melastomataceae (10 species; $3 \%$ ) and Arecaceae (8 species; $2 \%$ ). Moreover, amongst the elevational gradients surveyed, sub-montane ecosystems had the highest species richness $(n=287)$, followed by lowland $(n=96)$ and, lastly, montane $(n=53)$.

To understand the similarity of species in response to Lowland types along the elevation gradient, a cluster analysis was performed (Fig. 2). Plots were grouped into three major clusters as a function of abundance and composition. The first cluster was plots located in the lowland Lowland and was dominated by Axonopus compressus, Nephrolepis hirsutula, Chromolaena odorata, Christella parasitica and Melastoma malabathricum. Meanwhile, plots located in the sub-montane Lowland were grouped together in cluster two. This was dominated by Pinanga insignis, Nephrolepis biserrata, Selaginella eschscholzii, Aporosa sphaeridiophora and Pleioluma firma. Lastly, cluster three, plots from montane Lowland, was dominated by Cyathea negrosiana, Freycinetia lagenicarpa, Blechnum vestitum, Tasmannia piperita and Dacrydium beccarii.

\section{Species diversity and importance value}

\section{Lowland forest}

The diversity estimates along the elevation gradient tend to follow this trend, high > very high > low (Fig. 3). In lowland elevations, the Shannon Diversity Index was H' $=3.29$ which can be attributed to its fragmented vegetation under disturbed conditions. The presence of land preparation activities and agricultural farms has contributed to the removal of the Lowland cover (Pampilona et al. 2005). Consequently, pioneer and sun-loving species were accounted at this range in which agricultural crops like Cocos nucifera, Musa 
balbisana and Musa sapientum were also present (Suppl. material 1). Several pioneer species, such Ficus odorata, Leucosyke capitellata, Omolanthus populneus, Melicope latifolia, Macaranga bicolor, Macaranga tanarius, Ficus septica and Melastoma malabathricum, dominated the lowlands. The most common dominating species for ground cover in lowland includes Nephrolepis hirsutula, Chromolaena odorata, Christella parasitica, Nephrolepis biserrata, Lantana camara, Mikania cordata, Pteridium aquilinum and Panicum repens. These species were common in areas with high levels of sunlight, such as near agriculture and within Lowland gaps.

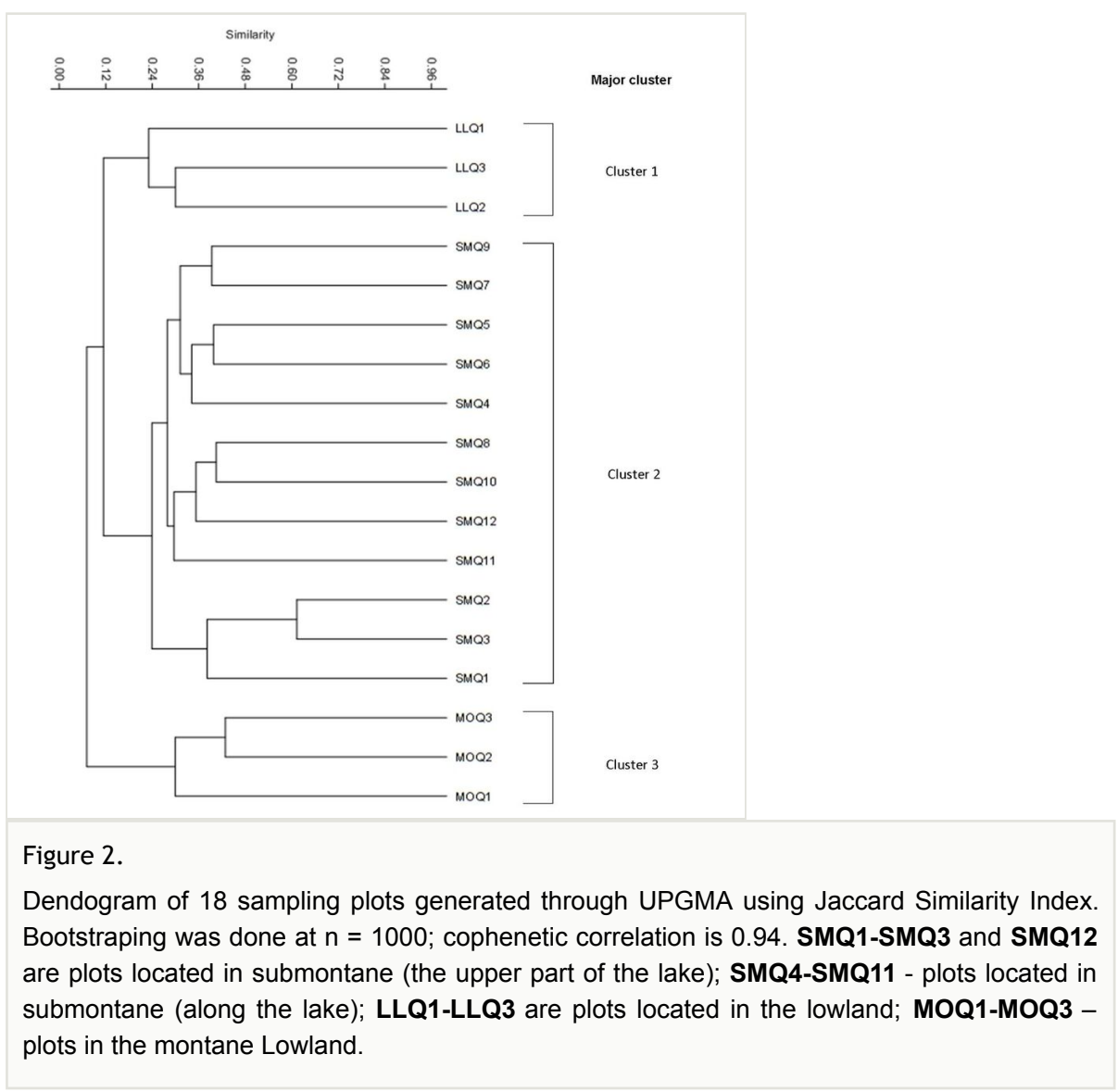

\section{Sub-montane Lowland}

Sub-montane Lowland has an average diversity of $H^{\prime}=4.20$ which was categorised as very high, based on Fernando (2008). The canopy layer, consisiting of tall economicallyimportant trees like Shorea polysperma, Agathis philippinensis, dominated in this Lowland (Suppl. material 2). Other frequent species that also tended to dominate were Streblus glaber, Platea excelsa, Syzygium affine, Aporosa sphaeridiophora and Phoebe sterculioides. Shorea negrosensis was found common in all types of terrain; however, it decreased in abundance at higher elevations. This trend was also observed for the other 
species listed. Huge mother trees of Agathis philippinensis were found only in a protected portion of the study area. It was noted that this species was very common many decades ago. The most abundant shrubs and small trees were Pleioluma firma, Euonymus javanicus, Schefflera elliptica and Pinanga insignis. Tree ferns like Cyathea contaminans and Cyathea negrosiana were also observed to be dominating in this Lowland. Ground cover was frequently dominated by several fern species, such as Nephrolepis biserrata, Christella parasitica and Selaginella eschscholzii. Dominant herb species were Aglaonema commutatum, Geophila repens and Scleria scrobiculata. The presence of Freycinetia lagenicarpa, which is a "ground-creeping" plant, was also encountered along branchlets of trees. The diversity and richness of this gradient were higher compared to lowland and montane.
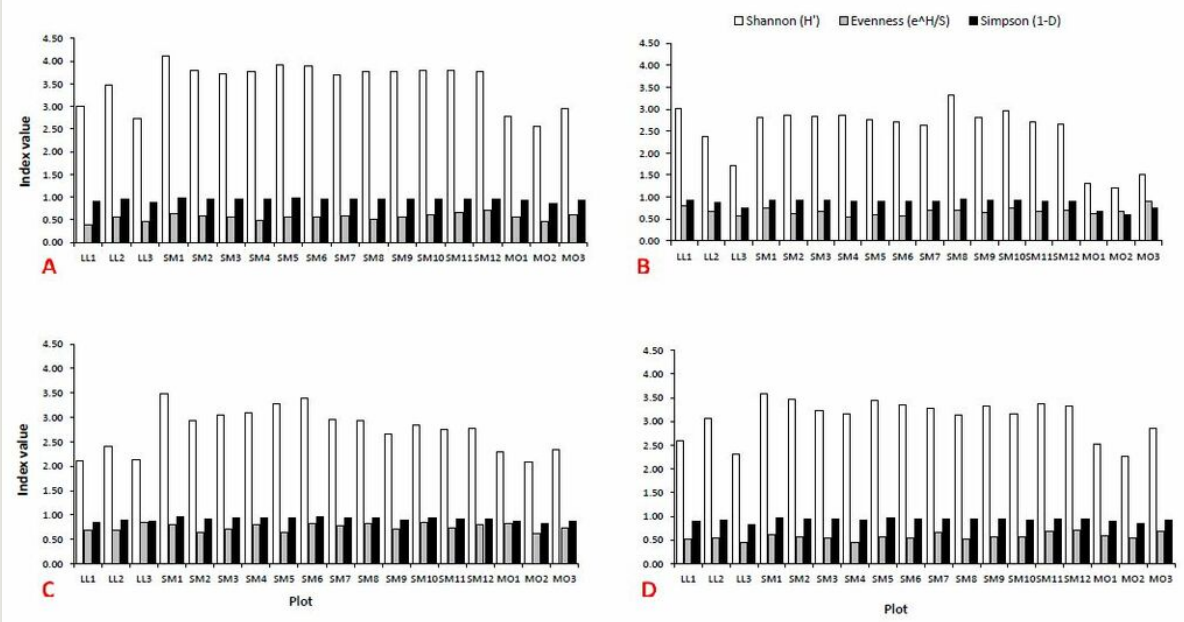

Figure 3.

The Shannon Diversity and the Pielou's Evenness Indices along elevational gradient in all plant layers (A), canopy (B), intermediate (C) and ground cover (D).

\section{Montane Lowland}

This Lowland is characterised by the presence of numerous species of mosses, lichens and epiphytes. The dominant tree species was Dacrydium beccarii, while common shrubs dominating were Tasmannia piperita, Elaeocarpus argenteus, Melastoma crinitum, Vaccinium microphyllum, Freycinetia lagenicarpa, Astronia cumingiana, Dimorphanthera apoana and Eurya buxifolia and species of tree ferns were Cyathea negrosiana and Cyathea contaminans (Suppl. material 3). A low Shannon Diversity Index, 2.48, was observed at this elevation. Computed Evenness on the other hand, was 0.79 which indicates even distribution of plant species commonly shared within the plots.

\section{Conservation status and endemicity}

Out of 351 species recorded at the study site, $30(9 \%)$ were classified as threatened. Of the 30 threatened species, six (6) were categorised as critically endangered, four (4) 
endangered and 20 vulnerable. Remarkably, twenty five of these threatened species were found thriving in the Lowland of the sub-montane (Table 3). Meanwhile, both lowland and montane had six threatened species noted. Critically-endangered species included Shorea almon, Paphiopedilum acmodontum, Shorea negrosensis, Shorea polysperma, Shorea contorta and Nepenthes ramos. Endangered species included Medinilla banahaensis, Madhuca betis, Guioa acuminata and Cyathea contaminans. Vulnerable species included Agathis philippinensis, Artocarpus blanco, Macaranga bicolor, Cinnamomum mercadoi, Dillenia philippinensis, Terminalia pellucida, Canthium dicoccum, Palaquium philippense, Palaquium luzoniense, Mangifera altissima, Canarium ovatum, Canarium luzonicum, Ardisia squamulosa, Macaranga grandifolia, Asplenium vittaeforme, Alocasia zebrina, Alpinia musifolia and Cyathea negrosiana. In addition, a total of 88 species were endemic to the Philippines. The highest number (74) of endemic species was found in the submontane followed by 20 in the montane and 15 in the lowland.

Table 3.

Threatened and endemic plant species recorded along the elevation gradient of BTLNP.

\begin{tabular}{|c|c|c|c|c|c|c|}
\hline \multirow[t]{2}{*}{ Seed type } & \multicolumn{3}{|l|}{ Endemic } & \multicolumn{3}{|c|}{ Threatened } \\
\hline & Lowland & Sub-montane & Montane & Lowland & Sub-montane & Montane \\
\hline Agiosperms & 13 & 71 & 18 & 4 & 21 & 4 \\
\hline Gymnosperms & 0 & 0 & 0 & 0 & 1 & 0 \\
\hline Pteridophytes & 2 & 3 & 2 & 2 & 3 & 2 \\
\hline Total & 15 & 74 & 20 & 6 & 25 & 6 \\
\hline
\end{tabular}

\section{Discussion}

The findings in this study showed that the composition of flora of "BTLNP" in Negros Island is structured by elevational gradient. The distribution and composition of species within the three major Lowland types in the study site are defined and restricted by the differences in elevation which have a direct influence on the species ability to survive, compete and reproduce. Several tree species from the family Lauraceae, such as Litsea, Cinnamomum, Neolitsea, Actinodaphne, Phoebe and Machilus, were found thriving in the sub-montane forests. In addition, a number of dipterocarp species belonging to genus Shorea were also observed in this Lowland type. These observations conformed with the findings of Ashton (2003) where sub-montane forests in Southeast Asia are mainly composed of dipterocarps and oak-laurel assemblages. The plant composition of the lowland Lowland, on the other hand, was predominantly agricultural crops and pioneer species such as banana (Musaceae), figs (Moraceae), legumes (Fabaceae), herbs (Araceae) and euphorbs (Euphorbiaceae), all considered indications of farm cultivation and anthropogenic influences. These species groups were also commonly observed in open forested areas of Bohol, Philippines as reported by Reyes et al. (2015) and Bullecer et al. (2015) and in native tree farms Reyes and Sarnowski (2020) and timber plantations Reyes (2019). The 
open Lowland canopy allows light to penetrate to reach the Lowland floor making it available to sun-loving ground herbs, legumes and grasses in order to proliferate which explains why these species are found dominant in the lowland Lowland (Durst et al. 2016). Ultimately, the montane Lowland was characterised by the presence of mosses, lichens, epiphytes and small trees with prop and aerial roots coming out from one to a few metres from the base of the tree trunks that are irregular in shape. Trees like Dacrydium, Tasmannia, Elaeocarpus, Melastoma, Omolanthus, Vaccinium and Syzygium were observed in this site to be dwarfed and their trunks gnarled. These are indications of their adaptations to strong winds and pressure, a similar observation by Aiba and Kitayama (1999). Furthermore, the dominance of tree ferns Cyathea contaminans and Cyathea negrosiana especially in sub-montane to montane elevations was observed. Cyathea is known to play a prominent role in lower montane Lowland areas (Richter 2008) and are common inhabitants of tropical montane cloud Lowland (Penafiel 1995). The wide range of tree ferns indicate a floral group more tolerant of higher seasonality and long-term climatic fluctuations (Tejedor 2018). Meanwhile, towards high elevations, the presence of conifers, known to thrive in higher Southeast Asian mountain areas, indicates the uniqueness of this elevational habitat (Enright and Jaffre 2011).

A sharp decline of species richness and diversity as altitude increased beyond 1,450 m a.s.I. was observed. This decline is due to the extreme environmental conditions, such as very low temperature, high relative humidity and low decomposition rate in the montane Lowland. Low temperature affects the respiratory process of trees through high retention of water vapour (Aureo and Bande 2019, Bernatzky 1978). Another contributary factor to the decrease in the number of species and diversity in the montane Lowland is organic matter storage and decomposition essential for plant growth (Culmsee and Leuschner 2013, Krishna and Mohan 2017). Low decomposition rates in the montane Lowland result in the building up of organic matter and nutrient stocks in soil which are not readily available for plant growth. Fast decomposition rates in submontane and lowland forests help to meet plant intake requirements (Isaac and Nair 2005). Another notable observation was that flora richness peaks at sub-montane and decreases at both lowlands and montane elevations which follow a bell shape curve. The diversity value of lowland was 3.29 , which is relatively high, but lower than sub-montane Lowland. Lowland elevation was identified primarily as agroforestry-dominated where human impacts are evident in the form of open spaces. This may prevent the establishment of shade-tolerant species (Villanueva and Buot 2018). The Evenness Index, an indication of species representation, was 0.88 or $88 \%$ for the lowland, demonstrating a high level of similarity between plots within the lowland habitat. This could be because of the presence of ecotones and the transition zone (from lowland to sub-montane) near the established plots in the lowland area. In sub-montane, the Shannon Diversity Index was very high. This can possibly be attributed to the various Lowland structures formed from transitional zones of lowland extending towards the lakes. Furthermore, submontane Lowland has a lower Evenness Index indicating that a certain species at this elevation over-dominate while other species are not well represented. As so many species were observed at the sub-montane level, it would not be expected for all species to be represented evenly. Montane Lowland, on the other hand, had low species diversity. In addition, the species Evenness Index value was 0.79 which indicates that $79 \%$ 
of the species amongst montane elevations are common amongst the plots. These findings correlate with previous tropical mountain research in which the number of species, genera and families decreases with increasing elevation (Aiba and Kitayama 1999, Kitayama 1992, Sharma et al. 2009). However, this finding is not consistent across other tropical mountains in the Philippines, such as in Mt. Pulag (Buot and Okitsu 1998), Mt. Mayon (Buot 2008), Mt. Makiling (Buot and Osumi 2011) and Mt. Ilong (Villanueva and Buot 2018), wherein an increase in diversity along elevation was observed. These contrasting observations could be explained by how a certain mountain ranges arebeing utilised. For instance, the lowland Lowland, which is located within $600-750 \mathrm{~m}$ a.s.I., is being utilised as agroforestry which accounts for both the planted and natural flora.

Thirty threatened and 88 Philippine endemic species were observed in BTLNP. Most of the threatened and endemic species were found in the sub-montane Lowland along the lake and are less in the montane and lowland. Elevation is known to be the greatest influencing factor in changes on floristic composition and diversity in tropical mountains (Hemp 2006). The threatened species found in BTNLP were mostly families belonging to Dipterocarpaceae and Sapotaceae which are mostly sensitive to extreme environmental conditions. Species belonging to the family Dipterocarpaceae, which was commonly found in this study, is known as a good source of timber and is considered economically important, thus constitutes a threat for future exploitation of these tree species (Reyes and Sarnowski 2020).

\section{Conclusions}

The present study highlights the floristic composition, community structure and diversity of BTLNP along its elevational gradient, from lowland, sub-montane and montane. Our findings revealed that lowland and sub-montane forests had higher number of species compared to the montane Lowland. Furthermore, we observed a change in plant species composition along elevation gradients with a trend of decreasing species diversity with increasing elevation. It is worth noting that most of the threatened species observed in this study are mostly found in the sub-montane Lowland and are more easily accessible to humans compared to the montane.

These results indicate that BTLNP should follow appropriate conservation and management strategies to protect all elevations, but have a special focus on the submontane level, as well as threatened species. Additional care should be taken in the development of ecotourism, as human distrubance has been shown to alter the floral composition. Lastly, this study not only provides a floral baseline for BTLNP, but can also be used as a reference for additional species composition and elevational research within the Central Visayas. 


\section{Acknowledgements}

The authors wish to thank Philippine Council for Agriculture, Aquatic and Natural Resources Research and Development (PCAARRD), for the financial assistance of the project. The Department of Environment and Natural Resources (DENR) and the Protected Area Management Board (PAMB) also with the BTLFAI Peoples Organization (PO) members of Balinsasayao Twin Lakes Natural Park is also acknowledged for allowing and supporting the researchers in the conduct of their study. We would like to also convey deep gratitude and heartfelt appreciation to the Central Visayas biodiversity survey team, Rochelyn Parba, Jessie Josol, Jessica Josol, Arianne Pacarat and Oscar Ido.

\section{Funding program}

Biodiversity Assessment for Sustainable Management in Key Biodiversity Areas of Central Visayas

\section{Hosting institution}

Bohol Island State University

\section{Ethics and security}

Specimen Collection Gratuitous Permit (GP) Number VII-2019-04 (DENR Region VII)

\section{Conflicts of interest}

The authors declare that there is no conflict of interest.

\section{References}

- $\quad$ Aiba S, Kitayama K (1999) Structure, Composition and Species Diversity in an Altitude Substrate Matrix of Rain Forest Tree Communities on Mount Kinabalu, Borneo. Plant Ecology (140)139-157. https://doi.org/10.1023/A:1009710618040

- $\quad$ Amoroso VB (2013) Philippine Medicinal Ferns and Lycopods. Central Mindanao University Publication Office, Musuan, Bukidnon.

- $\quad$ Ashton PS (1993) Philippine Phytogeography. Asia Life Science 2 (1): 1-8.

- $\quad$ Ashton PS (2003) Floristic composition of tree communities on wet tropical mountains revisited. Perspect Plant Ecology 6: 27-42. https://doi.org/10.1078/1433-8319-00044

- $\quad$ Aureo W, Bande M (2019) Impact of anthropogenic disturbance on Anurans habitat and species richness in Silago, Southern Leyte, Philippines. Journal of Biodiversity and and Environmental Science 15 (1): 38-45. https://doi.org/10.12983/ijsres-2017-p0082-0090 
- $\quad$ Aureo W, Jose R, Reyes TJ, Bucol L (2019) Anurans species diversity and composition along the elevational gradient of the Balinsasayao Twin Lakes Natural Park, Negros Oriental, Philippines. Journal of Biodiversity and Environmental Science.

- Barcelona J, Nickrent D, Lafrankie J, Callado JR, Pelser P (2013) Co's Digital Flora of the Philippines: plant identification and conservation through cybertaxonomy. Philippine Journal of Science (142)57-67.

- Bernatzky A (1978) Tree Ecology and Preservation. Elsevier Scientific Publishing Company [ISBN 9780444599384]

- Brooks TM, Evans TD, Dutson GC, Anderson GQ, Asane DC, Timmins RJ, Toledo AG (1992) The Conservation Status of the Birds of Negros. Bird Conservation International (2)273-302. https://doi.org/10.1017/S0959270900002501

- Brown WC, Alcala AC (1961) Populations of amphibians and reptiles in the submontane and montane forests of Cuernos de Negros, Philippine Islands. Ecology 42 (4):

628-636. https://doi.org/10.2307/1933494

- $\quad$ Bullecer RC, Reyes TJD, Labonite MA, Jose RP, Lomosbog NT, Labonite EKA, Ancog AB, Travero JT, B. A. B. Bautista J (2015) Mega Construction in Panglao Island, Philippines: The Magnitude of the Possible Biodiversity Losses. International Journal of Environmental and Rural Development 5 (2). https://doi.org/10.4324/9781315659046

- Buot IE, Okitsu S (1998) Vertical distribution and structure of the tree vegetation in the Montane Forest of Mt. Pulog, Cordillera Mountain Range, the highest mountain in Luzon Island. Philippines. Veg Sci (15)19-32. https://doi.org/10.15031/vegsci.15.19

- $\quad$ Buot IE (2008) Vertical distribution and zonation pattern of woody vegetation on the Northwestern Slope of Mt. Mayon, Philippines. Asia Life Sciences 2 (17): 189-205.

- Buot IE, Osumi K (2011) Land use pattern and woody species composition near humandisturbed landscapes on Mount Makiling, Luzon Island. Am J Environ Sci 4 (7): 306-315. https://doi.org/10.3844/ajessp.2011.306.315

- $\quad$ Corlett RT, Primack RB (2008) Tropical rainforest conservation: a global perspective. Tropical Forest Community Ecology. Blackwell Scienc 15 (51): 442-457.

- Co's Digital Flora of the Philippines (2020) https://www.philippineplants.org/

- Culmsee H, Leuschner C (2013) Consistent patterns of elevational change in tree taxonomic and phylogenetic diversity across Malesian mountain forests. J Biogeogr 40 ((10): 14). https://doi.org/10.1111/jbi.12138

- De Guzman E, Umali RM, Sotalbo ED (1986) Guide to Philippine Flora and Fauna: Dipterocarps and Non-Dipterocarps. [Natural Resources Management Center]. 3. Ministry of Natural Resources and University of the Philippines, $414 \mathrm{pp}$.

- DENR Administrative Order No. 11-17 (2017) Updated National list of Threatened Philippine Plants and their Categories. Philippine Plant Conservation Committee (PPCC) PAWB. DENR.

- Durst PB, Sajise P, Leslie RN (2016) Forest beneath the grass. Proceedings of the regional workshop on advancing the assisted natural regeneration for effective low-cost restoration Bohol, Philippine. Food and Agriculture Office of the United Nations Regional Office for Asia and the Pacific, Bangkok, Thailand. RAP Publication [ISBN 9789251066393; 9251066396].

- $\quad$ Eilu G, Obua J (2005) Tree condition and natural regeneration in disturbed sites of Bwindi Impenetrable Lowland natural park, southwestern Uganda. Tropical Ecology 46 (1): 99-111. 
- Enright NJ, Jaffre T (2011) Ecology and distribution of the Malesian podocarps. Sm C Bot 95: 57-78. https://doi.org/10.5479/si.0081024X.95.57

- $\quad$ Fernando E, Bande M, Piollo R, Sopot D, Dolotina N, Granert W (2009) Dipterocarpaceae of Bohol Island, Philippines. Asia Life Sciences 18: 121-138.

- $\quad$ Fernando ES, Sun BY, Suh MH, Kong HY, Koh KS (2004) Flowering Plants and Ferns of Mt. Makiling. ASEAN-Korea Environmental Cooperation Unit (AKECU). National Instrumentation Center for Environmental Management, College of Agriculture and Life Sciences, Seoul National University.

- Fernando ES (2008) Forest formations and flora of the Philippines. College of Forestry and Natural Resources. ASEAN-Korea Environmental Cooperation Unit.

- Flora Malesiana (2019) https://floramalesiana.org/new/. Accessed on: 2019-10-06.

- $\quad$ Glen S (2016) "Jaccard Index / Similarity Coefficient" From StatisticsHowTo.com:

Elementary Statistics for the rest of us! https://www.statisticshowto.com/jaccard-index/. Accessed on: 2020-9-18.

- Hamann A, Barbon EB, Curio E, Madulid DA (1999) A botanical inventory of a submontane tropical rainforest on Negros Island, Philippines. Biodiversity and Conservation (8)1017-1031. https://doi.org/10.1023/A:1008847704539

- Hammer $\varnothing$, Harper DA (2006) PAST. Paleontological Statistics. Version 2.07. Reference Manual. Blackwell Publishing.

- Heaney L (1993) Biodiversity patterns and the conservation of mammals in the Philippines. Asia Life Science (2)261-274.

- Heaney LR, Balete DS, Alcala A, Ong P, Dans AL, Rickart E, Gonzales P, Bias R. Tabaranza J, Ingle N, Utzurrum RB, Lepiten M, Dolar ML, Oliver WR (1998) A Synopsis of Mamalian Fauna of the Philippine Islands. Department of Zoology, Field Museum of Natural History. Field Museum of Natural History https://doi.org/10.5962/bhl.title.3419

- Heideman PD, Erickson KR (1987) The Climate and Hydrology of the Lake Balinsasayao Watershed, Negros Oriental, Philippines. Silliman Journal (34)82-107.

- Hemp A (2006) Continuum or zonation? Altitudinal gradients in the Lowland vegetation of Mt. Kilimanjaro. Plant Ecology 184: 27-42. https://doi.org/10.1007/s11258-005-9049-4

- Hicks M (2001) The National Parks and Other Wild Place of the Philippines. New Holland Publishers (UK) Ltd. [ISBN 9781859741948]

- Hughes AC (2017) Understanding the drivers of Southeast Asian biodiversity loss. Ecosphere 8 (1). https://doi.org/10.1002/ecs2.1624

- Humphries CJ, Williams PH, Wright RI (1995) Measuring Biodiversity Value for Conservation. Annual Review of Ecology and Systematics 1 (26): 93-111.

https://doi.org/10.1146/annurev.es.26.110195.000521

- International Plant Name Index (IPNI) (2016) https://www.ipni.org/. Accessed on: 2019-10-06.

- International Union for Conservation of Nature's Red List of Threatened Species (2019) https://www.iucnredlist.org/

- Isaac SR, Nair MA (2005) Biodegradation of leaf litters in the warm humid tropics of Kerala, India. Soil Biol Biochem (37)1656-1664. https://doi.org/10.1016/i.soilbio. 2005.02.002

- Kartawinata K (1989) A review of natural vegetation studies in Malesia with special reference to Indonesia. In Baas P (ed) The Plant Diversity of Malesiana. Kluwer Academic Publishers, Dordrecht, The Netherlands121-132. https://doi.org/ 10.1007/978-94-009-2107-8 12 
- Kitayama K (1992) An altitudinal transect study of the vegetation on Mount Kinabalu, Borneo. Vegetatio 102 (2): 149-171. https://doi.org/10.1007/BF00044731

- Krishna MP, Mohan M (2017) Litter decomposition in Lowland ecosystems: a review. Energy, Ecology and Environment 2: 236-249. https://doi.org/10.1007/ s40974-017-0064-9

- $\quad$ Lapitan PG, Fernando ES, Suh MH, Fuentes RU, Shin YK (2010) Biodiversity and Natural Resources Conservation in Protected Areas of Korea and the Philippines. Seoul: ASEAN-Korea Environmental Cooperation Unit [In English]. [ISBN 978-89-6558-009-6-9350]

- $\quad$ Lillo E, Baltazar A, Michael S, Nuevo R (2019) Native Trees on Mount Lantoy Key Biodiversity Areas (KBA), Argao, Cebu, Philippines. Philippine Journal of Science (148)365-377.

- Magurran A (1998) Ecological diversity and its measurement. Springer, Dordrecht [ISBN 978-94-015-7360-3] https://doi.org/10.1007/978-94-015-7358-0

- Malabrigo PLJ, David M, David-Pilar M (2016) BINHI: Tree for the Future, A Greening Legacy. Energy Development Corporation. CGKformprint, Inc, $336 \mathrm{pp}$.

- Mallari NA, Tabaranza BJ, Crosby MJ, Lepitan-Tabao M, Gee G (2001) Key conservation sites in the Philippines: A Haribon Foundation and Birdlife International Directory of important birds. Bookmark Inc., Makati City. [ISBN 971-596-405-5]

- $\quad$ Margules CR, Pressey RL (2000) Systematic conservation planning. Nature 405: 243-253. https://doi.org/10.1038/35012251

- McPherson S, Amoroso VB (2011) Field Guide to the Pitcher Plants of the Philippines. Redfern Natural History Productions Ltd, 61 pp. [ISBN 9780955891885]

- Merrill E (1922) An enumeration of Philippine flowering plants. Manila, Bureau of Printing,1922-26 https://doi.org/10.5962/bhl.title.49412

- Pampilona N, Torres M, Pinon A, Pollisco J, Duran N, Adiova J (2005) Biodiversity Resource in Southern Philippines: Vital for Sustainable Management of Mountain Ecosystems. The International Forestry Review. Commonwealth Forestry Association. In: Innes, J.L., Edwards, I.K., \& Wilford, D.J. (eds.). 7 (5): -37.

- Penafiel SR, et al. (1995) The Biological and Hydrological Values of the Mossy Forests in the Central Cordillera Mountains, Philippines. In: Hamilton L.S., Juvik J.O., Scatena F.N. (eds) Tropical Montane Cloud Forests. Ecological Studies (Analysis and Synthesis) Springer, New York, NY. 110: 266-273. https://doi.org/10.1007/978-1-4612-2500-3 18

- $\quad$ Reyes TD, Abadingo JB, Tabuno SG, Serino EKL (2015) Floristic Inventory of the Proposed Site for Tarsier Tourism Center in Villa Aurora, Bilar, Bohol, Philippines. Journal of Forest Science 9 (2): 67-74. https://doi.org/10.22146/jik.10188

- Reyes TD (2019) GIS-assisted Carbon Stock Assessment of Loboc-Bilar Mahogany Plantation, Bohol, Philippines. Journal of Environmental Science and Management 22 (1): 77-86.

- Reyes TD, Sarnowski MB (2020) Diversity and Carbon Stock Assessment of an Indigenous Philippine Tree Farm. IOP Conference Series: Earth and Environmental Science (449)12-33. https://doi.org/10.1088/1755-1315/449/1/012033

- $\quad$ Richter M (2008) Tropical mountain forests-Distribution and general features. In: Gradstein SR, Homeier J, Gansert D. (eds). The Tropical Mountain Forest-Patterns and Processes in a Biodiversity Hotspot. Universitätsverlag Göttingen, Germany. 
- $\quad$ Rojo JP, Salvosa FM, Forest Products Research and Development Institute (Philippines) (1999) Revised lexicon of Philippine trees. College, Philippines: Forest Products Research and Development Institute. Dept. of Science and Technology

- Rojo JR, Aragones EGJ, Forest Products Research and Development Institute (Philippines) (1997) Botanical identification handbook on Philippine dipterocarps. Laguna, Philippines: Forest Products Research and Development Institute. Department of Science and Technology, Laguna, Philippines, $97 \mathrm{pp}$.

- $\quad$ Sagar R, Raghubanshi AS, Singh JS (2008) Comparison of community composition and species diversity of understorey and overstorey tree species in a dry tropical Lowland of northern India. Journal of Environmental Management (88)1037-1946. https://doi.org/ 10.1016/j.jenvman.2007.05.013

- Salvosa FM (1963) Lexicon of Philippine Trees. College, Laguna, Philippines : Forest Products Research Institute [In English].

- $\quad$ Sharma CM, Suyal S, Gairola S, Ghildiyal SK (2009) Species richness and diversity along an altitudinal gradient in moist temperate Lowland of Garhwal Himalaya. Journal of American Science 5 (5): 119-128. URL: https://www.researchgate.net/publication/ 228591101

- $\quad$ Soepadmo E (1995) Plant diversity of the Malaysian tropical Lowland and its phytogeographical and economic significance. In Primack RB and Lovejoy TE (eds) Ecology. Conservation and Management of Southeast Asian Rainforest 19-40. https://doi.org/10.2307/j.ctt2250vnb.6

- $\quad$ Tandang DN, Tadiosa ER, Andes AP (2014) A Pictorial Handbook on Peat Swamp Flora of Agusan Marsh, Mindanao, Philippines. Biodiversity Management Bureau and National Museum of the Philippines, $322 \mathrm{pp}$.

- $\quad$ Tejedor A (2018) Diversity and endemism of tree ferns (Cyatheaceae: Polypodiopsida) in the Central Andes along latitudinal and elevation gradients. Acta Botanica Malacitana (42) 41-47. https://doi.org/10.24310/Actabotanicaabmabm.v42i2.2959

- Turner C, Tamblyn A, Dray R, Maunder L, Raines P (2003) The Biodiversity of the Upper Imbang-Caliban Watershed, North Negros Forest Reserve, Negros Occidental, Philippines. Coral Cay Conservation, London URL: www.coralcay.org

- Turner IM, Corlett RT (1996) The conservation value of small, isolated fragments of lowland tropical rain Lowland. Trends Ecol Evolut 11 (8): 330-333. https://doi.org/ 10.1016/0169-5347(96)10046-X

- Villanueva EL, Buot IE (2018) Vegetation analysis along the altitudinal gradient of Mt. Ilong, Halcon Range, Mindoro Island, Philippines. 19: 2163-2174. Biodiversitas (19) 2163-2174. https://doi.org/10.13057/biodiv/d190624

- Whitmore TC, Whitmore TC, Burnham CP (1984) Tropical Rain Forests of the Far East. 2, illustrated, reprint. Clarendon Press [ISBN 0198541368, 9780198541363]

- Williams P, Vane-Wright R, Humphries C (1995) Measuring Biodiversity Value for Conservation. Annual Review of Ecology and Systematics (26)93-111. https://doi.org/ 10.1146/annurev.es.26.110195.000521 


\section{Supplementary materials}

Suppl. material 1: Plant species with high IV in the lowland Lowland for the canopy, intermediate and ground layer. doi

Authors: Aureo et al.

Data type: excel

Brief description: RDen = relative density; $\mathrm{RFreq}=$ relative frequency; $\mathrm{RDom}=$ relative dominance; IV = importance value.

Download file $(11.31 \mathrm{~kb})$

Suppl. material 2: Plant species with the highest importance value in the sub-montane Lowland for the canopy, intermediate and ground layer. doi

Authors: Aureo et al.

Data type: excel

Download file $(11.31 \mathrm{~kb})$

Suppl. material 3: Plant species with high IV in the montane Lowland for the canopy, intermediate and ground layer. doi

Authors: Aureo et al.

Data type: excel

Download file $(11.93 \mathrm{~kb})$ 